\title{
PENGARUH BUDAYA ORGANISASI TERHADAP KINERJA PEGAWAI PADA DINAS PERHUBUNGAN KABUPATEN BONE BOLANGO
}

\author{
Lukman Hadju' ${ }^{1}$ \& Novita Adam² \\ Jurusan Sistem Informasi, STIMIK Ichsan Gorontalo \\ lukmanhadju743@gmail.com¹ \& adamnovita149@gmail.com²
}

\begin{abstract}
ABSTRAK
Budaya organisasi diyakini merupakan faktor penentu utama terhadap kesuksesan kinerja organisasi. Keberhasilan suatu organisasi untuk mengimplementasikan aspek-aspek atau nilai-nilai (values) budaya organisasinya dapat mendorong organisasi tersebut tumbuh dan berkembang secara berkelanjutan. Fenomena ini dilihat dari proses kerja dan kondisi pekerjaannya, waktu yang digunakan kurang bersesuaian yang mengakibatkan kesalahan. Dalam melaksanakan pekerjaan, jumlah dan jenis pemberian layanan dalam bekerja tidak sesuai, sehingga praktek semacam ini sudah saatnya berubah, terlebih lagi ketika undang-undang otonomi daerah telah menawarkan paradigma baru mengenai fungsi yang harus dijalankan oleh pemerintah daerah. Dengan perkataan lain, untuk menjalankan otonomi daerah diperlukan manajemen baru yang sesuai dengan dinamika persoalan yang dihadapi. Manajemen sumber daya manusia menjadi faktor yang sangat penting bagi keberhasilan implementasi otonomi daerah di Indonesia.

Metode yang digunakan dalam penelitian ini adalah metode kuantitatif dan hasil penelitian didapatkan bentuk persamaan fungsional dalam secara simultan sebagai berikut: Persamaan jalur: $\mathrm{Y}=0.340 \mathrm{X} 1+0.198 \mathrm{X} 2+0.342+0.847 \varepsilon$. Artinya budaya organisasi memang berpengaruh terhadap Kinerja Pegawai Dinas Perhubungan Kabupaten Bone Bolango.
\end{abstract}

\section{Kata Kunci: Budaya; Organisasi; Kinerja}

\section{PENDAHULUAN}

Suatu pola yang terdiri dari asumsi dasar yang dibentuk oleh suatu kelompok dengan tujuan mengatur dan mengatasi masalah baik yang dan akan timbul dalam suatu organisasi disebut Budaya organisasi. Sebuah instansi yang memiliki budaya kerja yang baik, dilihat peninjauan dari luar maupun dalam instansi tersebut. Tiap organisasi mempunyai suasana budaya kerja yang khas, begitu pula dengan Dinas perhubungan kabupaten Bone Bolango.

Untuk mengetahui kinerja pegawai dilakukan penilaian terhadap kerja pegawai, kinerja pegawai adalah hasil kerja pegawai baik dari segi kualitas maupun kuantitas berdasarkan standar kerja yang telah ditentukan. Kinerja individu ini akan tercapai apabila didukung oleh atribut individu, 
upaya kerja dan dukungan organisasi. Dengan kata lain kinerja individu adalah hasil dari atribut individu yang menentukan kapasitas untuk mengerjakan sesuatu yang meliputi factor individu, kemampuan, dan keahlian latar belakang serta demografi, dan faktor psikologis meliputi persepsi, attitude, personality, pembelajaran dan motivasi. Upaya kerja yang membentuk keinginan untuk mencapai sesuatu, serta dukungan organisasi yang memberikan kesempatan untuk berbuat sesuatu meliputi: sumber daya, kepemimpinan, lingkungan kerja, struktur organisasi dan job design.

Penentu sukses dan gagalnya kinerja dalam organisasi diyakini oleh para ahli mempunyai hubungan yang erat dengan budaya organisasi, sayangnya, perannya kurang disadari oleh pegawai, terutama Pimpinan dan pihak terkait yang dapat dipercaya untuk mengelola organisasi. Masalah-masalah didalam berbudaya organisasi yang terbagi atas Nilai Primer seperti konflik pemimpin dengan Pegawainya karena tak jelasnya tujuan, visi dann misi suatu Organisasi/instansi, pengambilan keputusan yang terburu - buru tanpa menimbang baik buruknya. Sedangkan nilai sekudernya adalah berfokus pada pelayanan Masyarakat, banyaknya kesalahan dalam melakukan pekerjaan yang mengakibatkan kesalahan dalam pengambilan

keputusan.Menunjukkan bahwa kesadaran manajemen terhadap peran strategis dan implementasi budaya organisasi dalam instansi masih sangat lemah dan mengkhawatirkan.

Kinerja sumber daya manusia beragam, seperti yang dapat dilihat pada Dinas Perhubungan Pariwisata Komunikasi dan Informatika di Kabupaten Bone bolango dimana ada pegawai yang kinerjanya kurang baik, kinerja yang cukup baik serta kinerja yang memuaskan.

Budaya organisasi diyakini merupakan faktor penentuutama terhadap kesuksesan kinerja organisasi. Keberhasilan suatu organisasi untuk mengimplementasikan aspek-aspek atau nilai-nilai (values) budaya organisasinya dapat mendorong organisasi tersebut tumbuh dan berkembang secara berkelanjutan.

Fenomena ini dilihat dari proses kerja dan kondisi pekerjaannya, waktu yang digunakan kurang bersesuaian yang mengakibatkan kesalahan. Dalam melaksanakan pekerjaan, jumlah dan jenis pemberian layanan dalam bekerja tidak sesuai, sehingga praktek semacam ini sudah saatnya berubah, terlebih lagi ketika undangundang otonomi daerah telah menawarkan paradigma baru mengenai fungsi yang harus dijalankan oleh pemerintah daerah. Dengan perkataan lain, untuk menjalankan otonomi daerah diperlukan manajemen baru yang sesuai dengan dinamika persoalan yang dihadapi. Manajemen sumber daya manusia menjadi faktor yang sangat penting bagi keberhasilan 
implementasi otonomi daerah di Indonesia.

Beragamnya kinerja pegawai pada Dinas Perhubungan Kabupaten Bone Bolango disebabkan oleh perubahan budaya.Dinas Perhubungan Kabupaten Bone bolango memiliki budaya tersendiri dalam pelaksanaan kegiatannya. Dengan adanya tantangan-tantangan baru atau aturan-aturan yang baru mengakibatkan penciptaan cara-cara baru dalam melakukan segala sesuatu, keluar masuknya anggota utama, asimilasi yang cepat oleh pegawai semuanya dapat memperlemah atau mengubah budaya organisasi sehingga kinerja yang ada fluktuatif.

\section{Percepatan}

perubahan

lingkungan berakibat pada perubahan budaya. Secara umum individu di latar belakangi oleh budaya yang mempengauhi perilakunya. Budaya menuntut individu untuk berperilaku dan memberi petunjuk pada mereka mengenai apa saja yang harus diikuti dan dipelajari. Kondisi tersebut berlaku pula dalam suatu organisasi. Bagaimana pegawai berperilaku dan apa yang seharusnya mereka lakukan, banyak dipengaruhi oleh budaya yang dianut oleh organisasi atau disebut budaya organisasi.

Kenyataannya, kinerja sumber daya aparatur pemerintahan kita yang buruk juga mengakibatkan rendahnya kinerja institusi pemerintah. Walaupun ada kenaikan gaji, tidak secara otomatis meningkatkan kinerja para pegawai negeri sipil. Persoalan kinerja inilah yang menjadi sumber kesinisan bagi masyarakat yang berurusan dengan birokrasi.

Banyaknya keluhan yang didapat dari pengguna jasa yang menyatakan bahwa kinerja organisasi publik adalah suatu proses keterlambatan administrasi dan kurang efisiensi. Serta keluhan mengenai aparatur pemerintah yang tidak memiliki inisiatif, inovatif, tidak transparan karena berpatokan terhadap hal-hal yang tertulis, malas-malasan, takut kepada atasan, sampai ketidakmampuannya dalam menjalankan tugas yang diberikan kepadanya. Sehingga dalam praktek penyelenggaraan pelayanan publik, masyarakat pengguna jasa selalu menjadi korban.

Berdasarkan

berbagai pernyataan mengenai budaya organisasi yang dikemukakan oleh beberapa ahli tersebut, dapat disimpulkan bahwa budaya organisasi dapat dijadikan sebagai pondasi bagi organisasi agar dapat terus mempertahankan citranya dalam keunggulan bersaing. Budaya suatu organisasi adalah kepribadian, dan kumpulan kepercayaan, nilai, gaya kerja, dan kerja sama yang membedakan satu organisasi dengan organisasi yang lainnya.

Ukuran variabel budaya organisasi dilihat dari kultur organisasi, yaitu suatu budaya yang kuat dengan tingkat sosialisasi anggota yang baik akan meningkatkan efektifitas dan efisiensi organisasi. Dimensi budaya organisasi tentang nilai-nilai organisasi yang terdiri dari nilai primer dan nilai sekunder. 


\section{STUDI LITERATUR}

\section{A. Budaya Organisasi}

Budaya (culture) berasal dari perkataan latin colere yang artinya mengolah, mengerjakan, menyuburkan, dan mengembangkan, terutama mengolah atau bertani. Atau bisa juga diartikan sebagai segala daya dan aktivitas untuk mengolah dan mengubah alam.

Dalam hubungan itu Miller (1987) dalam johanes basuki (2006:53) berpendapat kekuatan budaya organisasi harus didasarkan pada nilai - nilai, baik nilai - nilai yang telah terbentuk didalam organisasi maupun sistem nilai yang akan datang dari luar. Miller selanjutnya menyebut ada dua nilai yaitu delapan nilai primer dan empat nilai sekunder yang menjadi dasar budaya organisasi yaitu:

1. Nilai primer yaitu:
a. Nilai Tujuan,
b. Nilai pengambilan keputusan secara konsensus,
c. Nilai keunggulan,
d. Nilai kesatuan kepentingan,
e. Nilai imbalan,
f. Nilai empris,
g. Nilai keakraban,
h. Nilai integritas.

2. Nilai sekunder yaitu:
a. Nilai Terfokus pada masyarakat,
b. Nilai pengendalian yang disiplin,
c. Nilai kewirausahaan,
d. Nilai pengambilan keputusan yang cepat,
e. Nilai perencanaan jangka panjang/jangka pendek,

f. Nilai teknologi canggih.

\section{B. Pengertian Kinerja}

Kinerja atau performance adalah prestasi yang dihasilkan dari suatu proses, atau cara bertindak dalam suatu fungsi. Kinerja menempatkan suatu proses yang berkenaan dengan aktifitas sumber daya manusia dalam melakukan pekerjaan yang ditugaskan, mengingat kinerja adalah aktifitas yang berkaitan sesuatu (output). Demikian pula kinerja pegawai berkaitan dengan sistem dan standar yang dipergunakan organisasi dalam pencapaian tujuan.

Faktor yang mempengaruhi pencapaian kinerja adalah faktor kemampuan (ability) dan faktor motivasi (motivation). Hal ini sesuai dengan pendapat Keith Davis dalam AA.Anwar Prabu M (67:2000) sebagai berikut:

a. Faktor kemampuan, secara psikologis kemampuan terdiri dari kemampuan potensi dan kwemampuan reality artinya pimpinan dan pegawai yang memiliki IQ diatas rata-rata dan genius dengan pendidikan yang memadai untuk jabatannya dan terampil dalam mengerjakan pekerjaan sehari-hari, maka akan lebih mudah mencapai kinerja maksimal.

b. Faktor Motivasi, diartikan sebagai suatu sikap pimpinan dan pegawai terhadap situasi kerja di lingkungan organisasinya. Mereka yang bersikap positif terhadap situasi kerjanya akan menunjukkan motivasi kerja yang tinggi sebaliknya jika mereka bersifat negatif akan menunjukkan motivasi kerja yang 
rendah. Situasi kerja yang dimaksusd mencakup antara lain hubungan kerja, fasilitas kerja, iklim kerja, kebijakan pimpinan, pola kepemimpinan kerja dan kondisi kerja.

Menurut Henry Simamora (500:1995) kinerja dipengaruhi oleh tiga faktor, yaitu:

1. Faktor Lingkungan, yang terdiri dari:
a. Kemampuan dan Keahlian,
b. Latar Belakang,
c. Demografi.

2. Faktor Psikologis, yang terdiri dari:
a. Persepsi
b. Attitude
c. Personality
d. Pembelajaran
e. Motivasi.

3. Faktor Organisasi, yang terdiri dari:
a. Sumber Daya
b. Kepemimpinan
c. Penghargaan
d. Struktur
e. Job Design.

\section{Desain Penelitian}

\section{METODE PENELITIAN}

Desain dalam penelitian ini adalah jenis penelitian kuantitatif, yaitu penelitian yang memakai sampel dan menggunakan kuesioner sebagai alat pengumpulan data pokok.

\begin{tabular}{|c|c|c|}
\hline VARIABEL & $\begin{array}{c}\text { SUB } \\
\text { VARIABEL }\end{array}$ & INDIKATOR \\
\hline \multirow[t]{2}{*}{$\begin{array}{c}\text { Budaya } \\
\text { Organisasi }(X) \\
\text { Menurut Miller } \\
\text { dalam Johanes } \\
\text { Basuki } \\
(2006: 53)\end{array}$} & $\begin{array}{l}\text { Nilai Primer } \\
\text { (X1) }\end{array}$ & $\begin{array}{l}\text { 1. Nilai tujuan } \\
\text { 2. Nilai pengambilan keputusan } \\
\text { 3. Nilai keunggulan } \\
\text { 4. Nilai kesatuan kepentingan } \\
\text { 5. Nilai imbalan } \\
\text { 6. Nilai berpikir } \\
\text { 7. Nilai keakraban dan kekompakan } \\
\text { 8. Nilai integritas }\end{array}$ \\
\hline & $\begin{array}{l}\text { Nilai Sekunder } \\
\text { (X2) }\end{array}$ & $\begin{array}{l}\text { 1. Nilai berfokus pada Masyarakat } \\
\text { 2. Nilai pengendalian disiplin } \\
\text { 3. Nilai kewiraswastawan } \\
\text { 4. Nilai pengambilan keputusan cepat } \\
\text { 5. Nilai perencanaan jangka panjang } \\
\text { 6. Nilai teknologi canggih }\end{array}$ \\
\hline $\begin{array}{c}\text { Kinerja (Y) } \\
\text { Menurut } \\
\text { Mangkunegara } \\
(2006: 18)\end{array}$ & $\begin{array}{l}\text { 1. Aspek } \\
\text { kuantitatif }\end{array}$ & $\begin{array}{l}\text { 1. Proses kerja dan kondisi pekerjaan } \\
\text { 2. Waktu yang dipergunakan } \\
\text { melaksanakan pekerjaan } \\
\text { 3. Jumlah kesalahan dalam pekerjaan } \\
\text { 4. Jumlah dan jenis pemberian layanan } \\
\text { dalam bekerja }\end{array}$ \\
\hline
\end{tabular}




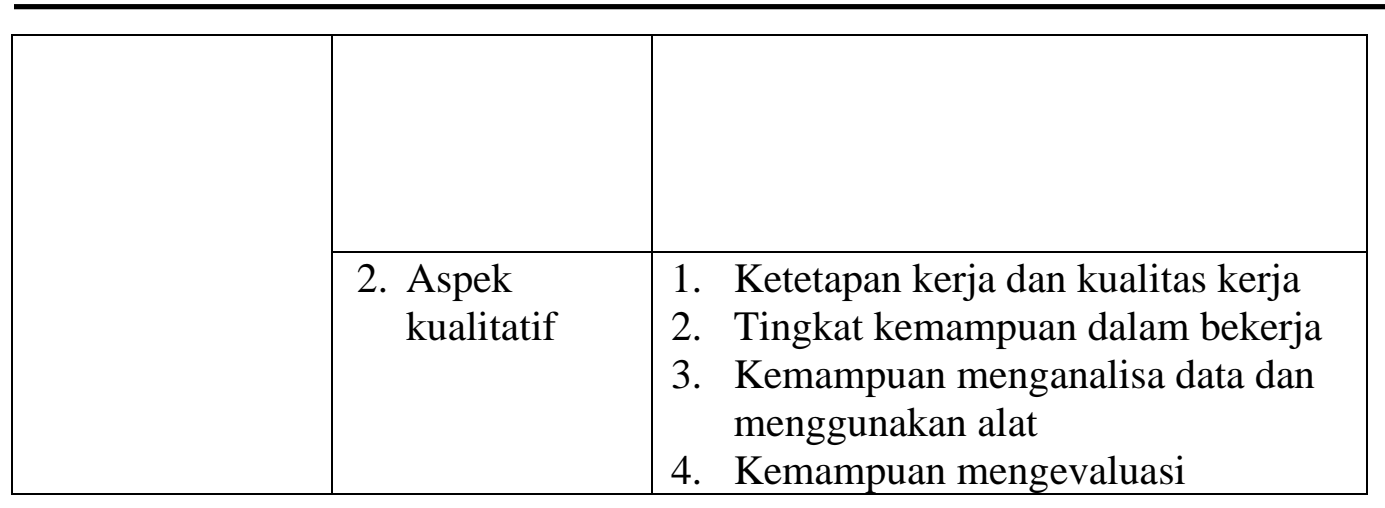

\section{Populasi Dan Sampel}

\begin{tabular}{|l|c|}
\hline \multicolumn{1}{|c|}{ Nama Bidang } & Jumlah Pegawai \\
\hline sekretariat & 12 \\
\hline Bidang Perhubungan & 7 \\
\hline Bidang Pengendalian dan Manajemen Lalu Lintas & 8 \\
\hline Bidang Pariwisata dan Kebudayaan & 13 \\
\hline Bidang Komunikasi dan Informatika & 7 \\
\hline UPTD & 2 \\
\hline Jumlah & 49 \\
\hline
\end{tabular}

\section{Prosedur Pengumpulan Data}

Dalam penulisan ini digunakan prosedur pengumpulan data sebagai berikut:

1. Dokumentasi, penulis akan melakukan pengamatan pada dokumen-dokumen maupun kearsipan yang menyangkut budaya organisasi dan kinerja;

2. Kuesioner, adalah daftar pertanyaan terstruktur yang ditujukan kepada para pimpinan dan pegawai.

\section{HASIL DAN PEMBAHASAN}

\section{Hasil Penelitian}

\section{Analisis pengaruh budaya organisasi $(X)$ secara simultan terhadap kinerja pegawai (Y)}

Penelitian ini digunakan untuk mengetahui seberapa besar pengaruh budaya organisasi (X) terhadap variabel kinerja (Y) pada Dinas Perhubungan baik secara parsial maupun simultan.

Tabel 4.13 Hasil Estimasi Pengujian Hipotesis 


\begin{tabular}{|l|l|l|l|l|l|}
\hline $\begin{array}{l}\text { Pengaruh } \\
\text { antar } \\
\text { variabel }\end{array}$ & $\begin{array}{l}\text { Besarnya } \\
\text { pengaruh }\end{array}$ & $\begin{array}{l}\text { Nilai } \\
\text { Sig }\end{array}$ & $\begin{array}{l}\text { Aplha } \\
(\boldsymbol{\alpha})\end{array}$ & Keputusan & Kesimpulan \\
\hline $\begin{array}{l}\mathrm{Y} \leftarrow \mathrm{X} 1 \\
\mathrm{X} 2\end{array}$ & 0.153 & 0.022 & 0.05 & Signifikan & Diterima \\
\hline $\mathrm{Y} \leftarrow \mathrm{X} 1$ & 0.340 & 0.016 & 0.05 & Signifikan & Diterima \\
\hline $\mathrm{Y} \leftarrow \mathrm{X} 2$ & 0.198 & 0.151 & 0.05 & Tdk Signifikan & Ditolak \\
\hline
\end{tabular}

Sumber: lampiran olah data

Dari tabel diatas menunjukkan bahwa model diatas dapat dijelaskan oleh variasi variabel budaya organisasi secara simultan atau identik bahwa besarnya koofisien jalur pengaruh budaya organisasi yang meliputi nilai primer (X1) dan nilai sekunder (X2) secara simultan berpengaruh positif dan signifikan terhadap variabel kinerja (Y) pada Dinas Perhubungan Pariwisata dan Informatika sebesar $0.153(15.3 \%)$, sedangkan secara parsial pengaruh sub variabel nilai primer (X1) berpengaruh positif dan signifikan terhadap variabel kinerja $(\mathrm{Y})$ sebesar 0.340 $(34.0 \%)$, pengaruh sub variabel nilai sekunder (X2) berpengaruh positif dan tidak signifikan terhadap variabel kinerja (Y) sebesar 0.198 (19.8\%)

Dari hasil estimasi pengujian hipotesis dan besarnya pengaruh variabel budaya organisasi (X) terhadap kinerja ( Y ) pada Dinas Perhubungan Kabupaten Bone Bolango, maka dapat digambarkan ke dalam model struktural jalur sebagai berikut:

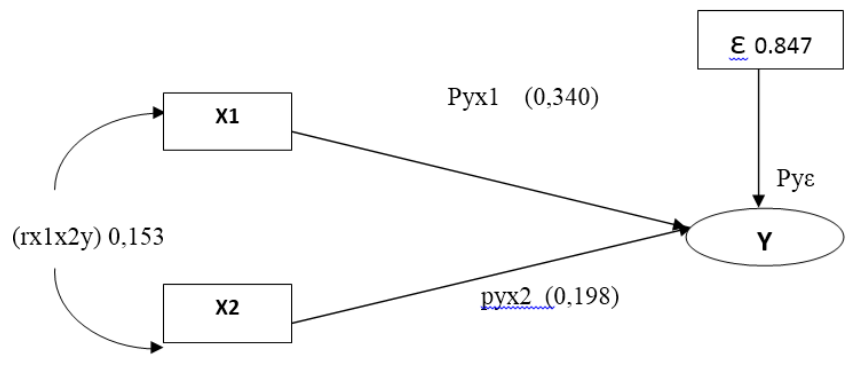

Gambar 4.1. Hubungan antara X1 dan X2 terhadap Y

Dari gambar diatas, maka dapat diperoleh bentuk persamaan fungsional dalam secara simultan sebagai berikut:

Persamaan jalur : $\mathrm{Y}=0.340 \mathrm{X} 1+0.198 \mathrm{X} 2+0.342+0.847 \varepsilon$. 
Hasil penelitian di atas dapat diringkas seperti pada Tabel di bawah sebagai berikut:

\section{Tabel}

Koefisien jalur, pengaruh langsung, tidak langsung, pengaruh total dan pengaruh nilai primer (X1) dan nilai sekunder (X2) secara simultan dan signifikan terhadap

Kinerja Pegawai (Y)

\begin{tabular}{|l|c|l|c|}
\hline \multirow{2}{*}{ Variabel } & \multicolumn{3}{|c|}{ Kontribusi } \\
\cline { 2 - 4 } & Langsung & $\begin{array}{c}\text { Tidak } \\
\text { Langsung }\end{array}$ & Total \\
\hline $\mathrm{Y} \leftarrow$ X1 & $\mathbf{0 , 3 4 0}$ & - & $\mathbf{3 4 \%}$ \\
\hline $\mathrm{Y} \leftarrow$ X2 & $\mathbf{0 , 1 9 8}$ & - & $\mathbf{1 9 . 8} \%$ \\
\hline $\begin{array}{l}\text { Pengaruh variabel X1, } \\
\text { X2 terhadap Y }\end{array}$ & $\mathbf{0 . 1 5 3}$ & - & $\mathbf{1 5 . 3 \%}$ \\
\hline $\begin{array}{l}\text { Pengaruh variabel } \\
\text { luar terhadap Y }\end{array}$ & $\mathbf{0 , 8 4 7}$ & - & $\mathbf{8 4 . 7 \%}$ \\
\hline TOTAL & & & $\mathbf{1 0 0 \%}$ \\
\hline
\end{tabular}

Sumber : Hasil Pengolahan Data Peneliti

Bedasarkan dari hasil yang signifikan terhadap kinerja penelitian terhadap 49 orang pegawai pegawai selama variabel lainnya Dinas Perhubungan Kabupaten konstant.

Hasil uji F membuktikan Bone Bolango menunjukkan bahwa nilai Primer pengaruh positif dan signifikan terhadap kinerja pegawai. Hal ini terlihat dari nilai signifikan sebesar 0,016 (yang lebih kecil 0,05). Sedangkan variabel nilai sekunder menunjukkan berpengaruh yang positif tapi tidak signifikan . Hal dapat dilihat dari hasil perhitungan Probability <́ $(0,151>$ $0,05)$. Ini berarti bahwa variabel nilai sekunder tidak mempunyai pengaruh 


\section{Pengaruh Nilai Primer (X1) Terhadap Kinerja Pegawai}

\author{
Secara parsial nilai primer \\ (X1) berpengaruh signifikan \\ terhadap kinerja pegawai (Y) pada \\ Dinas Perhubungan Kabupaten Bone \\ Bolango, artinya apabila variabel \\ nilai primer (X1), meningkat dan \\ variabel nilai sekunderl (X2), tetap \\ nilainya, maka akan menyebabkan \\ kinerja pegawai (Y) meningkat dan \\ sebaliknya bila variabel nilai primer \\ menurun akan menyebabkan kinerja \\ pegawai (Y) menurun.
}

Besarnya pengaruh tersebut dari pengamatan penulis menunjukkan bahwa nilai primer (X1) berpengaruh terhadap kinerja pegawai Dinas Perhubungan Kabupaten Bone Bolango sebesar $34 \%$. Dengan demikian hasil perhitungan uji statistik menunjukkan bahwa nilai primer berpengaruh signifikan. Hal dapat dilihat dari hasil perhitungan Probability <ó $(0,016<0,05)$. Ini berarti pula bahwa variabel nilai primer mempunyai pengaruh yang signifikan terhadap kinerja kerja pegawai selama variabel lainnya konstant.

\section{Pengaruh Nilai Sekunder (X2) terhadap Kinerja Pegawai (Y)}

Nilai sekunder yaitu Nilai Terfokus pada masyarakat, pada umumnya suatu instansi atau organisasi pemerintah menjadi focus utamanya adalah melayani masyarakat, bagaimana organisasi memberikan perhatian kepada masyarakat dengan memahami kebutuhan dan keinginan dari masyarakat, Nilai pengendalian yang disiplin. Setiap organisasi harus menerapkan suatu ukuran pengendalian bila oragnisasi tersebut ingin berfungsi efektif dan efisien, Nilai kewirausahaan, telah menjadi istilah yang bernilai positif, strategi kewiraswastaan mauun strategi yang telah terbukti benar dapat berhasil bila didasarkan pada suatu analisa ada tujuan yang jelas dan capaian yang diinginkan, Nilai pengambilan keputusan yang cepat, pengambilan jeputusan yang cepat telah menjadi suatu nilai budaya bagi organisasi yang maju, Nilai perencanaan jangka panjang/jangka pendek, perencanaan harus dilakukan untuk melaksanakan setiap tahapan kegiatan untuk menilai apakah suatu oragnisasi mampu mencapai setiap tujuan yang telah ditentukan, Nilai teknologi canggih, terkait dengan pengguna teknologi yang digunakan dalam menyukseskan setiap kegiatan dalam suatu organisasi.

Besarnya pengaruh tersebut dari pengamatan penulis menunjukkan bahwa nilai sekunder (X2) tidak berpengaruh signifikan terhadap kinerja pegawai Dinas Perhubungan Kabupaten Bone Bolango sebesar 19.8\%. Dengan demikian hasil perhitungan uji statistik 
menunjukkan bahwa nilai sekunder berpengaruh signifikan. Hal dapat dilihat dari hasil perhitungan Probability <́́ $(0,151>0,05)$. Ini berarti bahwa variabel nilai sekunder tidak mempunyai pengaruh yang signifikan terhadap kinerja pegawai selama variabel lainnya konstant.

\section{SIMPULAN}

\section{Dari hasil analisis dan pembahasan sebagaimana telah diuraikan diatas maka pada bagian ini akan ditarik kesimpulan sebagai berikut:}

1. Berdasarkan hasil uji hipotesis menunjukkan hasil sebesar $15.3 \%$, ini berarti kedua faktor variabel bebas yaitu nilai primer dan nilai sekunder secara bersama-sama mempunyai pengaruh positif terhadap kinerja pegawai Dinas Perhubungan Kabupaten Bone Bolango.

2. Secara sendiri-sendiri variabel nilai primer mempunyai pengaruh sebesar $34 \%$ terhadap kinerja pegawai Dinas Perhubungan Kabupaten Bone Bolango . Hasil penelitian menunjukkan bahwa nilai primer menempati posisi pertama yaitu sebesar $34 \%$ sehingga diperlukan upaya lebih memacu kinerja kerja pegawai.

3. Secara sendiri-sendiri variabel nilai sekunder mempunyai pengaruh sebesar $19.8 \%$ terhadap kinerja pegawai Dinas Perhubungan Kabupaten Bone Bolango . Faktor nilai sekunder menempati posisi kedua yakni 19.8\% ini berarti diperlukan upaya lebih memacu pegawai untuk meningkatkan kinerjanya.

\section{DAFTAR PUSTAKA}

Arikunto, Suharsimi. 2006. Prosedur Penelitian: Suatu Pendekatan Praktek. Edisi Revisi. Jakarta: PT. Rineka Cipta.

Al-Rasyid, H. 1994, Teknik Penarikan Sampel dan Penyusunan Skala. Bandung: Pasca SarjanaUNPAD.

Fathoni, Abdurrahmat. 2006. Organisasi dan Manajemen Sumber Daya Manusia .Jakarta: PT. Rineke Cipta

Hasibuan, Melayu, S.P (2005), Manajemen sumber daya manusia. Edisi Revisi, Jakarta: Bumi Aksara

Hadi, Sutrisno. 2009. Statistik Jilid II. Yogyakarta: YPFP-UGM.

Heijrahman, K. 2002. Teori dan Konsep Manajemen. Yogyakarta: BPFE .

Mathis Robert L dan Johan $\mathrm{H}$. Jackson. 1996. Manajemen Sumber Daya Manusia. Edisi 2. Jakarta: Salemba Empat.

Mangkunegara, AA. Anwar. Prabu. 2000. Manajemen Sumber Daya Manusia Perusahaan, Bandung: Remaja Rosda Karya. 
Riduwan, 2008. Skala Pengukuran Variabel-Variabel Penelitian, Cetakan Kedua. Bandung: : Alfabeta.

Sastrohadiwiryo, Siswanto. 2003.

Manajemen Tenaga Kerja Indonesia. Edisi Pertama. Cetakan Pertama. Jakarta: Bumii Aksara.

Simamora, Hendry,2003, Manajemen Sumber Daya Manusia, Sekolah tinggi Ilmu Ekonomi. Yogyakarta: andi offset.

Singarimbun, Masri. 2003. Metode Penelitian Survey. Jakarta: LP3ES.

Sondang P. Siagian. 2002. Kiat Meningkatkan Produktivitas Kerja, Cetakan Pertama. Jakarta: Rineka Cipta.

Sinungan, Muchkdarsyah. 2003. Dasar-Dasar Teknik Manajemen Kredit. Jakarta: Bumi Aksara.

Sulistiyani, Ambar $\mathrm{T} \&$ Rosidah. 2006. Manajemen Sumber Daya Manusia. Jakarta: Graha Ilmu.

Sugiyono. 1999. Metode, Penelitian Bisnis, Cetakan Pertama. Bandung: CV. Alfabeta.
Yuniarsih, Tjutju, dan Suwarno. 2009. Manajemen Sumber Daya Manusia, Teori, Praktek Dan Isu Penelitian. Bandung: CV Alfabet.

Wursanto, Ig. 2002. Dasar-Dasar Ilmu Organisasi. Yogyakarta: Andi. Offset. 